\title{
PENGARUH TEMPERATUR TEMPERING TERHADAP KEKERASAN DAN STRUKTUR MIKRO BAJA AISI 1045 YANG DIQUENCHING DALAM MEDIA PENDINGIN TERSIRKULASI
}

\author{
Hanif Mustofa ${ }^{1}$, Harnowo Supriadi ${ }^{1}$, Zulhanif $^{1}$ \\ 1) Jurusan Teknik Mesin, Fakultas Teknik Universitas Lampung \\ Jln. Prof.Sumantri Brojonegoro No. 1 Gedung H FT Lt. 2 Bandar Lampung \\ Telp. (0721) 3555519, Fax. (0721) 704947 \\ email : Hanifsp4@gmail.com
}

\begin{abstract}
Steel AISI 1045 is steel classified as medium carbon steel because it has a carbon content of $0.45 \%$. The characteristics of steel itself are sometimes not in accordance with the needs required, therefore the steel requires other treatments to change the properties and structure of steel AISI 1045. The characteristics of steel can be changed by giving heat treatment, one of the processes carried out is the quenching tempering process. Quenching is a metal working process with rapid cooling to a predetermined variety of media with the aim of increasing the hardness of AISI 1045 steel, while tempering is the process of reheating hardened steel with the aim of obtaining high tenacity and toughness. The quenching process uses a temperature of $800{ }^{\circ} \mathrm{C}$ with a waiting time of 60 minutes and then cooled quickly with variations of diesel, water, and salt water with a $180^{\circ}$ circulating process. While the tempering temperature variations used are $450^{\circ} \mathrm{C}, 550{ }^{\circ} \mathrm{C}$, and 650 ${ }^{\circ} \mathrm{C}$ with a waiting time of 60 minutes. The results of the hardness test using the Rockwell method. in raw material testing get a value of 61.33 HRB hardness. The quenching results circulated in the solar media are (80.6 HRB, 79.3 HRB, 81.3 HRB), the value of violence in the water media (89.3 HRB, 89 HRB, 89.6 HRB), and salt water media (94,6 HRB, 96 HRB, 94.6 HRB). The hardness value of temperature temperament $450{ }^{\circ} \mathrm{C}$ solar media $(72.6 \mathrm{HRB} 73 \mathrm{HRB}, 72.6 \mathrm{HRB})$, water media (83.6 HRB, 82.6 HRB, 83 HRB), salt water (86.3 HRB, 86.6 HRB, 87.3 HRB). Temper temperature hardness value of $550^{\circ} \mathrm{C}$ solar media namely (70.3 HRB, $70.3 \mathrm{HRB}, 70.6 \mathrm{HRB}$ ) water media (81.3 $H R B, 81.3 \mathrm{HRB}, 80.6 \mathrm{HRB})$ salt water media (84,3 HRB, 83.6 HRB, 84.6 HRB). The hardness value of temperature variation of $650^{\circ} \mathrm{C}$, solar media are $(68.3 \mathrm{HRB}, 68.6 \mathrm{HRB}, 68.6 \mathrm{HRB})$ water media (79 HRB, $79.3 \mathrm{HRB}, 79.3 \mathrm{HRB}$ ) and salt water media (81,3 HRB, 81.6 HRB, 82 HRB). The microstructure obtained in quenching is the martensite structure and the tempering structure is temper martensite.
\end{abstract}

Keywords: AISI 1045, quenching, tempering, martensite, ferrite, pearlite, HRB

\section{PENDAHULUAN}

Seiring dengan perkembangan yang semakin maju, mendorong para pelaku dunia industri untuk meningkatkan kebutuhan penggunaan dari hasil pengerasan baja yang dibutuhkan konsumen. Perkembangan teknologi terutama dalam pengerasan logam mengalami kemajuan yang sangat pesat. Untuk memenuhi tuntutan konsumen dalam teknik pengerasan logam ini peneliti mencoba mengangkat permasalahan logam pada baja AISI 1045 karena baja tersebut sangat banyak digunakan dalam bidang industri khususnya dalam dunia outomotif. Pengerasan dapat dilakukan dengan quenching. Quenching adalah memanaskan benda kerja hingga temperatur austenisasi dilanjutkan dengan proses pencelupan di dalam media pendingan.

Proses quenching menghasilkan suatu produk kekerasan yang baik, getas dan terdapat tegangan sisa untuk mengurangi kekerasan, kegetasan dan menghilangkan tegangan sisa 
maka perlu dilakukan suatu proses tempering. Tempering adalah suatu proses pemanasan ulang baja hingga mencapai temperatur dibawah temperatur kritis dan menahannya pada temperatur tersebut untuk jangka waktu tertentu [1].

Baja adalah logam paduan antara besi (Fe) dan karbon (C), dimana besi sebagai unsur dasar dan karbon sebagai unsur paduan utamanya. Kandungan karbon dalam baja berkisar antara $0,1 \% \quad-1,7 \%$ sesuai tingkatnya. Proses pembuatan baja akan terdapat suatu unsurunsur lain, selain karbon yang akan tertinggal di dalam baja seperti mangan (Mn), silikon (Si), kromium (Cr), vanadium (V), dan unsur lainya. Berdasarkan komposisi dalam praktiknya baja terdiri dari beberapa macam yaitu: Baja Karbon, dan Baja Paduan [2].

Proses perlakuan panas terdiri dari beberapa tahapan, dimulai dari proses pemanasan bahan hingga pada suhu tertentu dan selanjutnya didinginkan juga dengan cara tertentu. Tujuan dari perlakuan panas adalah mendapatkan sifatsifat mekanik yang lebih baik dan sesuai dengan yang diinginkan seperti meningkatkan kekuatan dan kekerasan, mengurangi tegangan, melunakkan, mengembalikan pada kondisi normal akibat pengaruh pada pengerjaan sebelumnya, dan menghaluskan butir kristal yang akan berpengaruh pada pengerjaan sebelumnya, dan menghaluskan butir kristal yang akan berpengaruh pada keuletan bahan [3].

Dalam penelitian ini penulis menggunakan suatu metode perlakuan panas quenchingtempering dengan media pendingin tersirkulasi dan bukaan katup penuh dengan variasi media pendinginan air, air garam, dan solar, pengujian kekerasan menggunakan metode rockwell. Karena dari banyak literatur dan jurnal, media pendingin yang tersirkulasi dapat meningkatkan kekerasan suatu baja hingga $40 \%$.

Dalam penelitian ini penulis menggunakan baja AISI 1045 sebagai spesimen. Baja AISI 1045 adalah baja karbon yang mempunyai kandungan karbon sekitar 0,43\% - 0,50\% dan termasuk golongan baja karbon menengah [4].
Berdasarkan penelitian dari Mizhar Susri tentang Analisa Kekerasan dan Struktur Mikro Terhadap Variasi Temperatur Pada Baja AISI 4140. Dengan variasi temperatur tempering yaitu $200{ }^{\circ} \mathrm{C}, 300{ }^{\circ} \mathrm{C}, 400{ }^{\circ} \mathrm{C}, 500{ }^{\circ} \mathrm{C}$, dan 600 ${ }^{\circ} \mathrm{C}$ dengan waktu tahan 2 jam. Proses normalizing mendapatkan nilai kekerasan 38,2 $\mathrm{HRC}$, nilai mengalami kenaikan setelah di hardening menjadi 52 HRC kenaikan sekitar $26 \%$. Proses tempering dengan suhu $200{ }^{\circ} \mathrm{C}$ nilai kekerasan tidak mengalami penurunan malah sebaliknya sekitar $0,5 \%$, pada temperatur $300{ }^{\circ} \mathrm{C}$ nilai kekerasan mengalami penurunan sekitar 3\% menjadi $50 \mathrm{HRC}$, temper $400{ }^{\circ} \mathrm{C}$ nilai kekerasan menurun sekitar $8 \%$ menjadi $47,4 \mathrm{HRC}$, temper $500{ }^{\circ} \mathrm{C}$ turun sekitar $23 \%$ menjadi $40 \mathrm{HRC}$ dan pada temper $600{ }^{\circ} \mathrm{C}$ kekerasan penurunan yang sangat drastis sekitar 33\% menjadi 34,5 HRC [5].

Menurut penelitian sebelumnya dengan proses Quenching menggunakan baja AISI 1045 yang tersirkulasi dengan pengujian metode vikers diperoleh sebagai berikut Q1 pengujian RAW material mendapatkan hasil $130 \mathrm{HVN}$, Q2 tanpa agitasi $(\mathrm{V}=0 \mathrm{~m} / \mathrm{s})$ dengan kekerasan 308 VHN, Q3 dengan kecepatan $(\mathrm{V}=0,597 \mathrm{~m} / \mathrm{s})$ dengan kekerasan 417,6 VHN, Q4 dengan kecepatan $(\mathrm{V}=0,696 \mathrm{~m} / \mathrm{s})$ dengan kekerasan 429,3 VHN, dan Q5 dengan kecepatan (V= $0,833 \mathrm{~m} / \mathrm{s}$ ) dengan kekerasan $735 \mathrm{VHN}$ dapat disimpulkan dari penelitian tersebut bahwa semakin cepat aliran media pendigin maka hasil kekerasan yang diperoleh akan semakin tinggi [6].

Oleh Haryadi Gunawan Dwi yang berjudul Pengaruh Suhu Tempering Terhadap Kekerasan, Kekuatan Tarik dan Struktur Mikro Pada Baja K-460. Hasil pengujian yang telah dilakukan setelah proses tempering dengan variasi suhu telah merubah kekerasanny. Kekerasan baja setelah pemanasan menurun ketika suhu tempering dinaikkan. Perubahan suhu tempering juga mempengaruhi nilai kekutan tarik. Dengan material dasar yang berbeda yaitu dengan baja K-460, proses tempering dengan variasi suhu yang berbeda dengan data $100{ }^{\circ} \mathrm{C}$ kekuatan tarik maksimumnya 2014,8 Mpa, dan suhu $200^{\circ} \mathrm{C}$, $300^{\circ} \mathrm{C}$, dan $400{ }^{\circ} \mathrm{C}$ masing masing kekuatan tarik maksimumnya adalah 1671,1 Mpa, 
1444,6 Mpa, dan 1023,3 Mpa dari hasil pengujian menunjukkan bahwa nilai kekerasan, kekuatan tarik dan struktur mikro dipengaruhi oleh suhu tempering. Ketika suhu tempering dinaikkan kekerasan dan kekuatan tariknya akan menurun [7].

\section{METODELOGI PENELITIAN}

Pada penelitian ini dilakukan pengujian nilai kekerasan dengan metode rockwell skala B dan analisis struktur mikro.

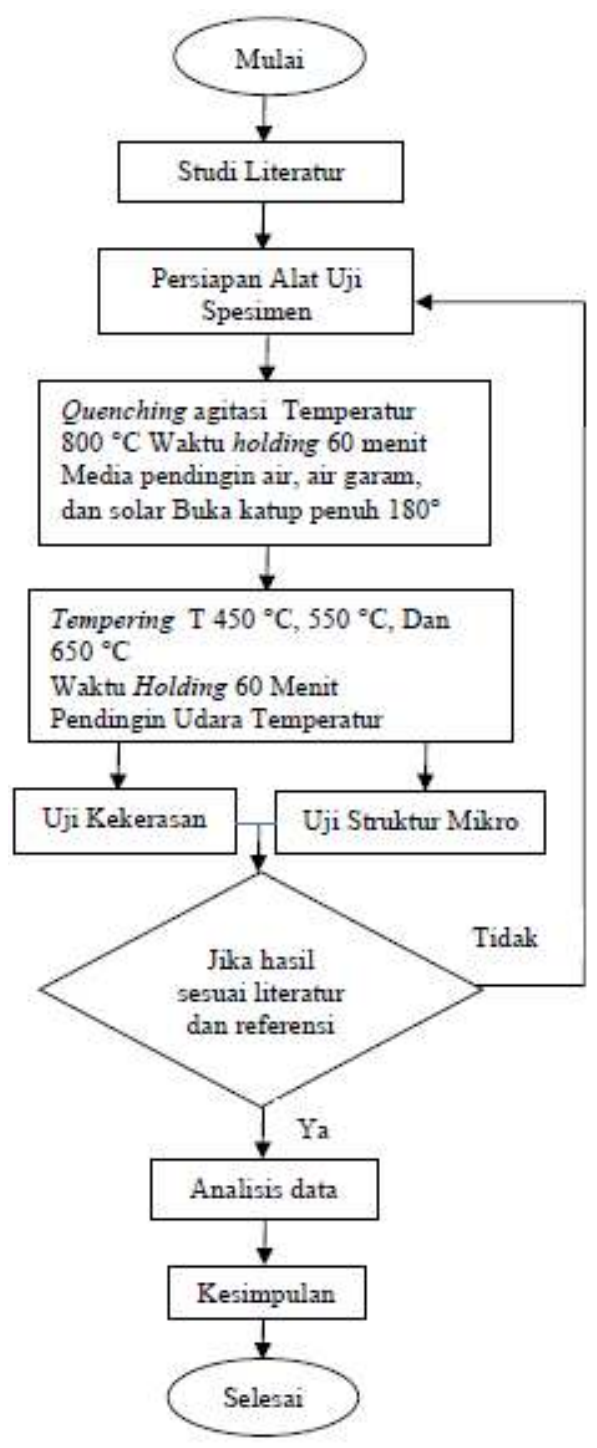

Gambar 1. Diagram alir penelitian

\section{Alat dan Bahan}

Pada penelitian ini penulis menggunakan alat instalasi quenching tersirkulasi dan bahan bahan yang mendukung dalam melakukan penelitian.

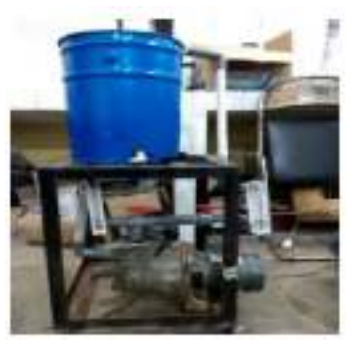

Gambar 2. Alat instalasi sistem quenching tersirkulasi

Pada penelitian ini spesimen yang telah dinaikkan temperaturnya dengan menggunakan furnace langsung dimasukkan kedalam alat instalasi quenching tersirkulasi yang telah dirancang dan dibuat pada penelitian sebelumnya, alat ini menggunakakan pompa untuk mensirkulasikan media pendingin yang digunakan dengan katup sebagai pengatur kecepatan dan flowmeter untuk melihat besarnya debit aliran media pendingin.

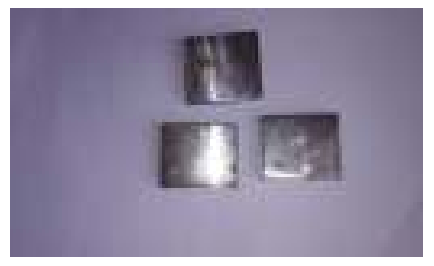

Gambar 3. Baja AISI 1045

Baja AISI 1045 merupakan baja karbon sedang dengan kadar karbon 0,45\%. Baja AISI 1045 digunakan karena berdasarkan pada referensi dari penelitian yang telah dilakukan sebelumnya, adapun beberapa spesifikasinya spesimen berbentuk plat persegi empat yang digunakan untuk pengujian kekerasan dengan ukuran panjang $33 \mathrm{~mm}$, lebar $25 \mathrm{~mm}$, dan tebal $4 \mathrm{~mm}$. Pemotongan spesimen menggunakan gerinda potong. 
Kemudian spesimen dinaikkan temperaturnya dengan dimasukkan kedalam furnace hingga mencapai suhu $800^{\circ} \mathrm{C}$ dan dilakukan holding time selama 60 menit. Baja yang sudah dipanaskan tadi dikeluarkan dari furnace lalu dengan segera mungkin spesimen dimasukkan kedalam alat instalasi quenching tersirkulasi yang telah disiapkan variasi media pendinginnya alat ini diletakkan berdekatan dengan furnace agar meminimalisir durasi kontak dengan udara. Pada alat instalasi quenching tersirkulasi dilakukan variasi media pendingin dan bukaan katup serta mengamati debit aliran media dengan memperhatikan flowmeter yang sudah terpasang pada alat tersebut pada tiap media dan bukaan katup digunakan sebanyak 3 spesimen. Setelah proses quenching selesai semua maka di lanjutkan proses tempering yaitu proses pemanasan ulang.

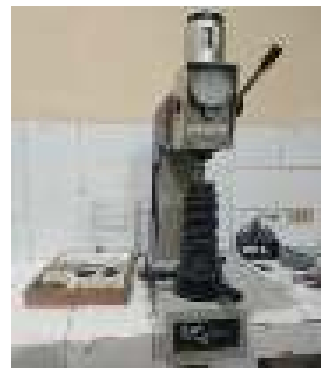

Gambar 4. Universal Hardness Tester

Universal Hardness tester merupakan alat uji kekerasan. Pengujian kekerasaan dilakukan dengan metode Rockwell skala B dimana dengan menggunakan diameter bola baja $1 / 16 "$.

\section{HASIL DAN PEMBAHASAN}

\section{A. Hasil}

Dari pengujian yang sudah dilakukan maka didapatkan beberapa data yang akan dijelaskan adalah sebagai berikut:
1. Nilai kekerasan Baja AISI 1045 adalah sebagai berikut:

Tabel 1. Nilai kekerasan raw material Baja AISI 1045

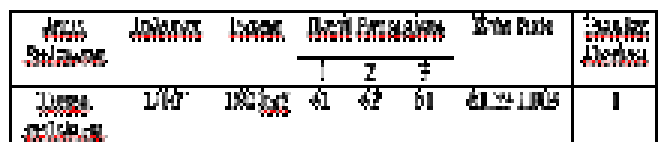

\section{Hasil Pengujian Variasi Media Pendingin, Bukaan Katup Penuh dan Tempering.}

Maka dari hasil pengujian yang dilakukan di Lab Material Teknik Universitas Lampung dan LIPI Tanjung Bintang pada 21 Februari - 07 Oktober 2019, data hasil kekerasan variasi media pendingin pada baja AISI 1045 yang disirkulasikan bukaan katup penuh adalah sebagai berikut:

2. Nilai Kekerasan Baja AISI 1045 Yang Diquenching Dengan Media Air

Tabel 2. Data Quenching Hasil Uji Kekerasan Pengujian Media Air

\begin{tabular}{|c|c|c|c|c|c|c|c|}
\hline \multirow{3}{*}{$\begin{array}{c}\text { Dosary } \\
1\end{array}$} & \multirow{3}{*}{ Hota } & \multirow{3}{*}{ 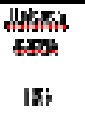 } & \multirow{3}{*}{ 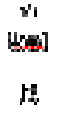 } & \multirow{3}{*}{$\begin{array}{l}4 \pi \\
\text { is }\end{array}$} & \multicolumn{2}{|c|}{ एकाम } & \multirow{3}{*}{ 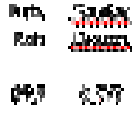 } \\
\hline & & & & & & $\dot{a}$ & \\
\hline & & & & & \& & EF & \\
\hline 5 & Mis. & $J F_{z}$ & If & is & 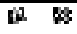 & 51 & F \\
\hline & & IXp & $\bar{\mu}$ & TI & $6 \square$ & Sk & $\$ 4$ \\
\hline
\end{tabular}

3. Nilai Kekerasan Baja AISI 1045 Yang Diquenching Dengan Media Air Garam

Tabel 3. Data Quenching Hasil Uji Kekerasan Pengujian Media Air Garam

\begin{tabular}{|c|c|c|c|c|c|c|c|c|c|}
\hline \multirow[b]{2}{*}{ 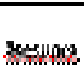 } & \multirow[b]{2}{*}{ hikto } & \multirow{2}{*}{$\begin{array}{l}\text { yluts } \\
\text { yoh }\end{array}$} & \multirow{2}{*}{ ix } & \multirow{2}{*}{ 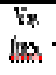 } & \multicolumn{3}{|c|}{ SWOK } & \multirow{2}{*}{ Rith } & \multirow{2}{*}{$\begin{array}{l}\text { Elugdas } \\
\text { thation }\end{array}$} \\
\hline & & & & & $A$ & K & sith & & \\
\hline 1 & 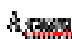 & 林 & .2 & t2. & $\$$ & لנ & w & 2,4 & 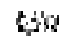 \\
\hline$\hbar$ & 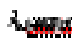 & $k \geqslant$ & $\nu$ & b & k. & $w$ & 98 & H & \\
\hline 3 & k $z$ wan & {$[3]$} & : & & $x$ & $\boldsymbol{N}$ & 45 & $: 4$ & \\
\hline
\end{tabular}


4. Nilai Kekerasan Baja AISI 1045 Yang Diquenching Dengan Media Solar

Tabel 4. Data Quenching Hasil Uji Kekerasan Pengujian Media Solar

\begin{tabular}{|c|c|c|c|c|c|c|c|}
\hline \multirow{2}{*}{ iatrin? } & \multirow{2}{*}{ Mots } & \multirow{2}{*}{ 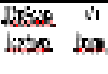 } & \multirow{2}{*}{$\begin{array}{l}\text { 1. } \\
4 \% 2\end{array}$} & \multicolumn{2}{|r|}{ (IIIIII) } & \multirow{2}{*}{\multicolumn{2}{|c|}{ 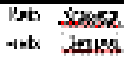 }} \\
\hline & & & & 4 & $\begin{array}{ll}\bar{y} & \overline{j u}\end{array}$ & & \\
\hline 1 & $7+b x$ & 165 & id & EO & $\mathrm{Ni}$ & की & as!? \\
\hline 2 & with & 150 & (6) & \& & 4 & 125 & osyy \\
\hline I & sofx & 180 & .1 & Z: & पa & 21,3 & $85 ?$ \\
\hline
\end{tabular}

5. Nilai Kekerasan Baja AISI 1045 Quenching Tempering Temperatur $450{ }^{\circ} \mathrm{C}$

Tabel 5. Data Tempering Temperatur 450 ${ }^{\circ} \mathrm{C}$ Media Air

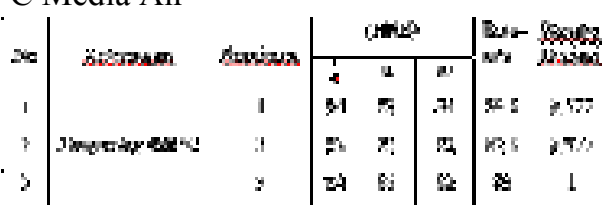

6. Nilai Kekerasan Baja AISI 1045 Quenching Tempering Temperatur $550{ }^{\circ} \mathrm{C}$

Tabel 6. Data Tempering Temperatur 550 ${ }^{\circ} \mathrm{C}$ Media Air

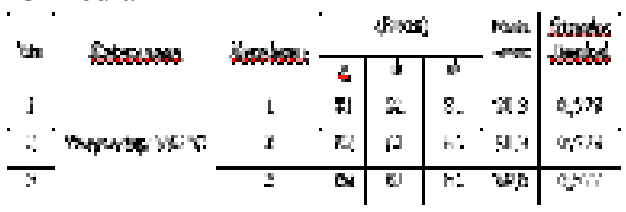

7. Nilai Kekerasan Baja AISI 1045 Quenching Tempering Temperatur $650{ }^{\circ} \mathrm{C}$

Tabel 7. Data Tempering Temperatur 650 ${ }^{\circ} \mathrm{C}$ Media Air

\begin{tabular}{|c|c|c|c|c|c|c|c|}
\hline \multirow[b]{2}{*}{$\mathbf{n}$} & \multirow[b]{2}{*}{$x_{\text {toseds. }}$} & \multirow[b]{2}{*}{ 3eskes } & \multicolumn{3}{|c|}{ JCE } & \multirow{2}{*}{ tis } & \multirow{2}{*}{ 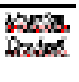 } \\
\hline & & & $b$ & is & :i & & \\
\hline 1 & \multirow{3}{*}{ Styp; } & 7 & W & 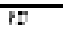 & का & 72 & \\
\hline$\overline{7}$ & & $\mathrm{r}$ & 721 & & 7 & $5 \%$ & $1.1 \% 1$ \\
\hline 3 & & 3 & $\ddot{z}$ & st & 79 & $x \equiv$ & Q5r: \\
\hline
\end{tabular}

8. Nilai Kekerasan Baja AISI 1045 Quenching Tempering Temperatur $450{ }^{\circ} \mathrm{C}$

Tabel 8. Data Tempering Temperatur 450 ${ }^{\circ} \mathrm{C}$ Media Air Garam

\begin{tabular}{|c|c|c|c|c|c|c|c|}
\hline \multirow[b]{2}{*}{ W: } & \multirow[b]{2}{*}{ Kavewas } & \multirow[b]{2}{*}{ 5x:ivs } & \multicolumn{3}{|c|}{$0: \Omega 4$} & \multirow{2}{*}{$\begin{array}{c}\overline{\pi n n} \\
\text { did }\end{array}$} & \multirow{2}{*}{$\operatorname{linhls}_{\mathrm{Kans}}$} \\
\hline & & & 4. & 4 & $\bar{a}$ & & \\
\hline$T$ & \multirow{3}{*}{ Donpustapes 1} & $T$ & W; & $\overline{E n}$ & re & $\mathrm{ES}$ & n,m \\
\hline$\pi$ & & $\bar{\pi}$ & Wi & $\bar{C} ?$ & 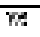 & $\overline{\varepsilon x k}$ & $\mathrm{~kg}$ \\
\hline$\therefore$ & & ; & $7 x$ & $9 ?$ & $7 i$ & $8 ! 4$ & $\overline{2} ; \overline{3}$ \\
\hline
\end{tabular}

9. Nilai Kekerasan Baja AISI 1045 Quenching Tempering Temperatur $550{ }^{\circ} \mathrm{C}$

Tabel 9. Data Tempering Temperatur 550 ${ }^{\circ} \mathrm{C}$ Media Air Garam

\begin{tabular}{|c|c|c|c|c|c|c|c|}
\hline \multirow[b]{2}{*}{$x_{*}$} & \multirow[b]{2}{*}{ Bewrowar. } & \multirow[b]{2}{*}{ 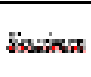 } & \multicolumn{3}{|c|}{ WW } & \multirow{2}{*}{$\begin{array}{l}\text { bens } \\
\text { cene }\end{array}$} & \multirow{2}{*}{ 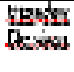 } \\
\hline & & & 1 & in & $\dot{a}$ & & \\
\hline 1 & & 1 & Wh & जा & WA & लू. & 252 \\
\hline$T$ & 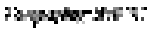 & $\pi$ & 4 & ल & $\bar{n}$ & Ebs & मूक \\
\hline 3 & & $\nabla$ & 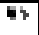 & $\mathrm{F}$ & $x_{1}$ & mx & म5. \\
\hline
\end{tabular}

10. Nilai Kekerasan Baja AISI 1045 Quenching Tempering Temperatur $650{ }^{\circ} \mathrm{C}$

Tabel 10. Data Tempering Temperatur 650 ${ }^{\circ} \mathrm{C}$ Media Air Garam

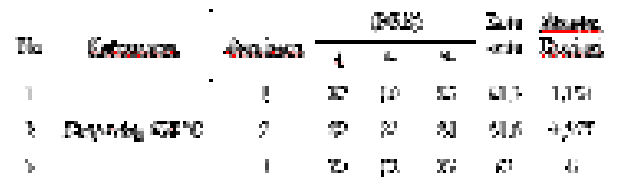

11. Nilai Kekerasan Baja AISI 1045 Quenching Tempering Temperatur $450{ }^{\circ} \mathrm{C}$

Tabel 11. Data Tempering Temperatur 450 ${ }^{\circ} \mathrm{C}$ Media Solar

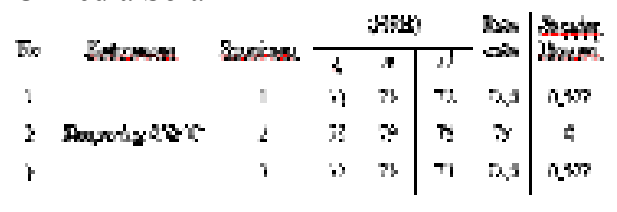


12. Nilai Kekerasan Baja AISI 1045 Quenching Tempering Temperatur $550{ }^{\circ} \mathrm{C}$

Tabel 12. Data Tempering Temperatur 550 ${ }^{\circ} \mathrm{C}$ Media Solar

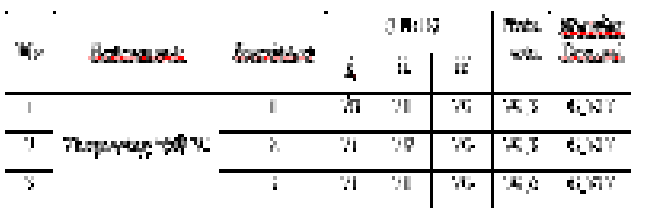

13. Nilai Kekerasan Baja AISI 1045 Quenching Tempering Temperatur $650{ }^{\circ} \mathrm{C}$

Tabel 13. Data Tempering Temperatur 650 ${ }^{\circ} \mathrm{C}$ Media Solar

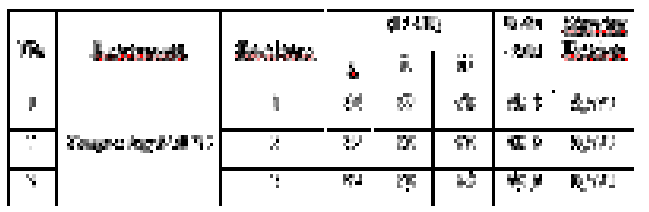

\section{PEMBAHASAN}

Pada penelitian ini menggunakan jenis baja AISI 1045 spesimen berbentuk plat persegi empat dengan ukuran panjang $33 \mathrm{~mm}$, lebar 25 $\mathrm{mm}$, dan tebal $4 \mathrm{~mm}$, yang dilakukan proses quenching pada $800{ }^{\circ} \mathrm{C}$ dan ditahan selama 60 menit, kemudian dicelupkan kedalam variasi media fluida pendingin yang disirkulasikan (air, air gram, dan solar) dan pada bukaan katup penuh. Pada masing-masing media pendingin dan bukaan katup penuh kecepatan dipengaruhi oleh densitas fluida masingmasing media pendingin. Media air memiliki densitas $1000 \mathrm{~kg} / \mathrm{m}^{3}$, garam dapur atau halit memiliki densitas $2,17 \mathrm{~g} / \mathrm{m}^{3}$, dan solar jenis HSD (High Speed Diesel) memiliki densitas minimal $815 \mathrm{~kg} / \mathrm{m}^{3}$ dan maksimal $870 \mathrm{~kg} / \mathrm{m}^{3}$. Semakin rendah densitas suatu fluida maka aliran yang didapatkan akan semakin besar. Setelah dilakukan proses quenching kemudian dilakukan proses tempering dengan temperatur yang berbeda yaitu $450{ }^{\circ} \mathrm{C}, 550{ }^{\circ} \mathrm{C}$, dan $650{ }^{\circ} \mathrm{C}$ dengan waktu masing-masing penahan 60 menit. Setelah dilakukan proses quenchingtempering kemudian baja AISI 1045 dilakukan beberapa pengujian untuk mengetahui kekuatan mekanik berupa pengujian kekerasan dan struktur mikro.

Pada pengujian menggunakan kekerasan Rockwell menggunakan skala B dengan beban $100 \mathrm{~kg}$ dan menggunakan indentor yang diameter 1/16". Pengujian kekerasan Rockwell pada permukaan spesimen diambil kekerasannya dibeberapa titik yang sudah ditentukan dan setiap spesimen diambil tiga titik pengujian. Pengujian pertama adalah baja AISI 1045 tanpa perlakuan (RAW material), pengujian $R A W$ material ini menggunakan satu spesimen yang diambil tiga titik pada permukaan yang berbeda di daerah permukaan spesimen panjang dan lebar, dengan menggunakan metode Rockwell mendapatkan hasil $61 \mathrm{HRB}, 62 \mathrm{HRB}$, dan $61 \mathrm{HRB}$ dengan nilai rata-rata $61,33 \mathrm{HRB}$, maka didapatkan nilai error atau standar deviasi 1 .

Pengujian kekerasan yang dilakukan dengan menggunakan baja AISI 1045 yang diquenching menggunakan media air yang disirkulasikan dan bukaan katup penuh dengan debit aliran $12 \mathrm{Lpm}$. pengujian pada media air menggunakan tiga spesimen yang berbeda pada spesimen pertama didapatkan rata-rata 89,3 HRB, pada spesimen yang kedua di dapatkan hasil rata-rata $89 \mathrm{HRB}$, dan pada spesimen yang ketiga di dapatkan hasil ratarata 89,6 HRB, pengujian pada media air garam yang disirkulasikan dan bukaan katup penuh dengan debit aliran $10 \mathrm{Lpm}$, pengujian pada media air garam menggunakan tiga spesimen yang berbeda pada spesimen pertama didapatkan hasil rata-rata 94,6 $\mathrm{HRB}$, spesimen kedua dengan hasil rata-rata $96 \mathrm{HRB}$, dan spesimen ketiga didapatkan hasil rata-rata 94,6 HRB. Selanjutnya pengujian kekerasan yang diquenching menggunakan media solar yang disirkulasikan dan bukaan katup penuh dengan debit aliran $11 \mathrm{Lpm}$, pada spesimen pertama mendapatkan hasil rata-rata 80,6 HRB, pada spesimen kedua mendapatkan hasil rata-rata $79,3 \mathrm{HRB}$, dan yang ketiga hasil rata-rata 81,3 HRB.

Pengujian kekerasan menggunakan spesimen baja AISI 1045 yang diquenching-tempering media air dengan temperatur temper masingmasing $\left(450{ }^{\circ} \mathrm{C}, \quad 550{ }^{\circ} \mathrm{C}\right.$, dan $\left.650{ }^{\circ} \mathrm{C}\right)$, pengujian pada media air ini menggunakan 9 
spesimen yang berbeda yang masing-masing spesimen pada temperatur temper $450{ }^{\circ} \mathrm{C}$ memiliki spesimen 3 , pada temperatur temper $550{ }^{\circ} \mathrm{C}$ memiliki 3 spesimen dan pada temperatur temper $650{ }^{\circ} \mathrm{C}$ memiliki 3 spesimen. Setelah dilakukan pengujian kekerasan Rockwell temperatur tempering 450 ${ }^{\circ} \mathrm{C}$ maka didapatkan hasil rata-rata yaitu $(83,6$ HRB, 82,6 HRB, dan 83 HRB). Pada temperatur tempering $550{ }^{\circ} \mathrm{C}$ maka didapatkan hasil rata-rata yaitu $(81,3 \mathrm{HRB}, 81,3 \mathrm{HRB}$, dan 80,6 HRB). Pengujian kekerasan pada temperatur tempering $650{ }^{\circ} \mathrm{C}$ maka didapatkan hasil rata-rata yaitu (79 $\mathrm{HRB}, 79,3 \mathrm{HRB}$, dan 79,3 HRB.

Pengujian kekerasan menggunakan spesimen baja AISI 1045 yang di quenching-tempering media air garam dengan temperatur temper masing-masing $\left(450{ }^{\circ} \mathrm{C}, 550{ }^{\circ} \mathrm{C}\right.$, dan $\left.650{ }^{\circ} \mathrm{C}\right)$, pengujian pada media air garam ini menggunakan 9 spesimen yang berbeda yang masing-masing spesimen pada temperatur temper $450{ }^{\circ} \mathrm{C}$ memiliki spesimen 3 , pada temperatur temper $550{ }^{\circ} \mathrm{C}$ memiliki 3 spesimen dan pada temperatur temper $650{ }^{\circ} \mathrm{C}$ memiliki 3 spesimen. Setelah dilakukan pengujian kekerasan Rockwell temperatur tempering 450 ${ }^{\circ} \mathrm{C}$ maka didapatkan hasil rata-rata yaitu $(86,3$ HRB, 86,6 HRB, dan 87,3 HRB). Pengujian kekerasan Rockwell temperatur tempering 550 ${ }^{\circ} \mathrm{C}$ maka didapatkan hasil rata-rata yaitu $(84,3$ HRB, 83,6, dan 84,6 HRB). Pengujian kekerasan Rockwell temperatur tempering 650 ${ }^{\circ} \mathrm{C}$ maka didapatkan hasil rata-rata yaitu $(81,3$ HRB, 81,6 HRB, dan $82 \mathrm{HRB}$ ).

Pengujian kekerasan menggunakan spesimen baja AISI 1045 yang di quenching-tempering media solar dengan temperatur temper masingmasing $\left(450{ }^{\circ} \mathrm{C}\right.$, $550{ }^{\circ} \mathrm{C}$, dan $\left.650{ }^{\circ} \mathrm{C}\right)$, pengujian pada media solar ini menggunakan 9 spesimen yang berbeda yang masing-masing spesimen pada temperatur temper $450{ }^{\circ} \mathrm{C}$ memiliki spesimen 3, pada temperatur temper $550{ }^{\circ} \mathrm{C}$ memiliki 3 spesimen dan pada temperatur temper $650{ }^{\circ} \mathrm{C}$ memiliki 3 spesimen. Setelah dilakukan pengujian kekerasan Rockwell temperatur tempering 450 ${ }^{\circ} \mathrm{C}$ maka didapatkan hasil rata-rata yaitu $(72,6$ HRB, $73 \mathrm{HRB}$, dan 72,6 HRB). Pengujian kekerasan Rockwell temperatur tempering 550
${ }^{\circ} \mathrm{C}$ maka didapatkan hasil rata-rata yaitu $(70,3$ HRB, 70,3 HRB, dan 70,6 HRB). Pengujian kekerasan Rockwell temperatur tempering 650 ${ }^{\circ} \mathrm{C}$ maka didapatkan hasil rata-rata yaitu $(68,3$ HRB, 68,6 HRB, dan 68,6 HRB).

Dari hasil yang telah dijelaskan dengan detail tersebut didapatkan grafik variasi media pendingin yang berbeda yaitu solar, air, dan air garam dengan proses quenching, secara umum, hasil pengujian kekerasan secara rata-rata yang didapat terlihat dalam gambar 5 berikut ini.

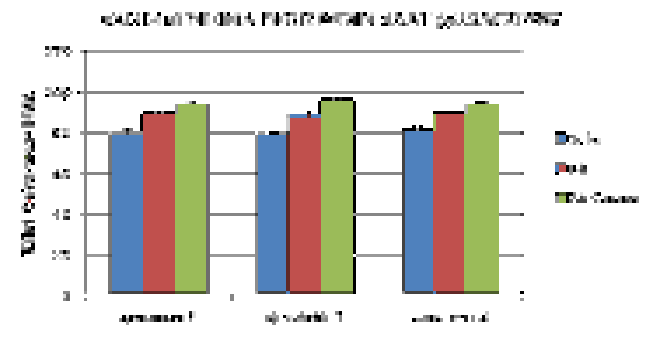

Gambar 5. Grafik hubungan variasi media pendingin saat quenching

Dari grafik diatas dapat dilihat kenaikan pada setiap variasi media pendingin yang disirkulasikan dimana hasil pengujian kekerasan yang terbaik yaitu menggunakan media air garam dengan nilai kekerasan 94,6 HRB, 96 HRB, dan 94,6 HRB. Air garam mendapatkan nilai kekerasan yang terbaik karena air gram memiliki cepat rambat dingin yang lebih cepat dibandingkan dengan media air dan solar, sehingga menghasilkan kekerasan yang paling tinggi.

Dengan hasil yang telah dijelaskan dengan detail tersebut didapatkan grafik temperatur tempering $450{ }^{\circ} \mathrm{C}$ dengan variasi media yang berbeda yaitu solar, air, dan air garam dengan proses quenching tempering, secara umum, hasil pengujian kekerasan secara rata-rata yang didapat terlihat dalam gambar 6.

Dari grafik gambar 6, yaitu pada temperatur tempering $450{ }^{\circ} \mathrm{C}$ dapat dilihat setiap kenaikan nilai kekerasan yang tertinggi yaitu pada media air garam dengan nilai kekerasan didapat adalah 86,3 HRB, 86,3 $\mathrm{HRB}$, dan 87,3 HRB, dan nilai paling rendah pada media solar yaitu 
72,6 HRB, 73 HRB, dan 72,6 HRB. Dan mengalami kenaikan nilai kekerasan dengan variasi air yaitu 83,6 HRB, 82,6 HRB,dan 83 HRB.

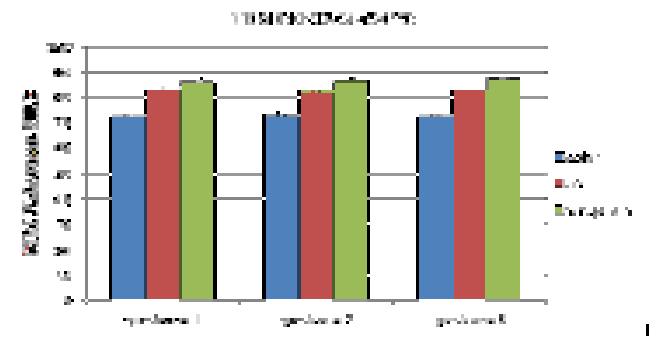

Gambar 6. Grafik hubungan variasi temperatur tempering $450{ }^{\circ} \mathrm{C}$

Dari grafik diatas yaitu pada temperatur tempering $450{ }^{\circ} \mathrm{C}$ dapat dilihat setiap kenaikan nilai kekerasan yang tertinggi yaitu pada media air garam dengan nilai kekerasan didapat adalah 86,3 HRB, 86,3 HRB, dan 87,3 HRB, dan nilai paling rendah pada media solar yaitu 72,6 HRB, 73 HRB, dan 72,6 HRB. Dan mengalami kenaikan nilai kekerasan dengan variasi air yaitu 83,6 HRB, 82,6 HRB, dan 83 HRB.

Gambar 7. merupakan gafik temperatur tempering $550{ }^{\circ} \mathrm{C}$ dengan variasi media yang berbeda yaitu solar, air, dan air garam dengan proses quenching tempering, secara umum, hasil pengujian kekerasan secara rata-rata yang didapat terlihat pada gambar dibawah

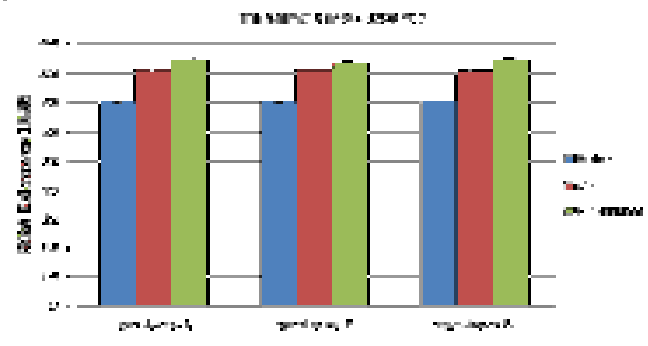

Gambar 7. Grafik hubungan variasi temperatur tempering $550{ }^{\circ} \mathrm{C}$

Hasil pengujian kekerasan menunjukkkan bahwa material AISI 1045 yang telah mengalami proses quenching tempering pada air garam memiliki nilai kekerasan yaitu 84,3
HRB, 83,6 HRB, dan 84,6 HRB, pada media air mendapatkan nilai kekerasan yaitu 81,3 $\mathrm{HRB}$, 81,3 HRB, dan 80,6 HRB, dan pada media solar dengan nilai kekerasan yaitu 70,3 HRB, 70,3 HRB, dan 70,6 HRB.

Dengan hasil yang telah dijelaskan dengan detail tersebut didapatkan grafik temperatur tempering $650{ }^{\circ} \mathrm{C}$ dengan variasi media yang berbeda yaitu solar, air, dan air garam dengan proses quenching tempering, secara umum, hasil pengujian kekerasan secara rata-rata yang didapat terlihat dalam gambar 8 . berikut ini

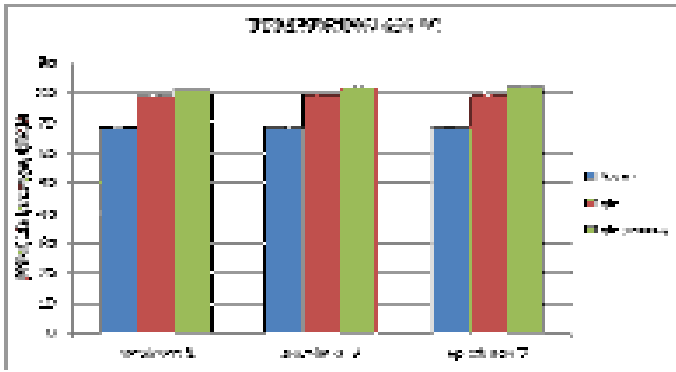

Gambar 8. Grafik hubungan variasi temperatur tempering $650{ }^{\circ} \mathrm{C}$

Hasil pengujian kekerasan menunjukkkan bahwa material AISI 1045 yang telah mengalami proses quenching tempering pada air garam memiliki nilai kekerasan yaitu 81,3 HRB, 81,6 HRB, dan $82 \mathrm{HRB}$, pada media air mendapatkan nilai kekerasan yaitu 79 HRB, 79,3 HRB, dan 79,3 HRB, dan pada media solar dengan nilai kekerasan yaitu 68,3 HRB, 68,6 HRB, dan 68,6 HRB.

Data rata-rata keseluruhan pengujian ini dengan proses quenching dan spesimen yang ditempering dengan temperatur $450{ }^{\circ} \mathrm{C}, 550$ ${ }^{\circ} \mathrm{C}$, dan $650{ }^{\circ} \mathrm{C}$. secara umum, hasil pengujian kekerasan yang dapat terlihat dalam gambar 9 .

Dari grafik gambar 9 memperlihatkan bahwa untuk nilai kekerasan setelah perlakuan heat treatment dan melakukan quenching pada proses quenching nilai kekerasan yang paling tinggi pada media air garam yaitu 95,06 HRB dan yang paling rendah pada media solar yaitu 80,4 HRB. Adapun yang penguji lakukan selanjutnya yaitu proses tempering. Dari nilai kekerasan untuk setiap perlakuan pada gambar 
22 terlihat untuk suhu tempering dari yang terendah $\left(450{ }^{\circ} \mathrm{C}\right)$ sampai yang tertinggi $(650$ $\left.{ }^{\circ} \mathrm{C}\right)$ nilai kekerasannya semakin kecil.

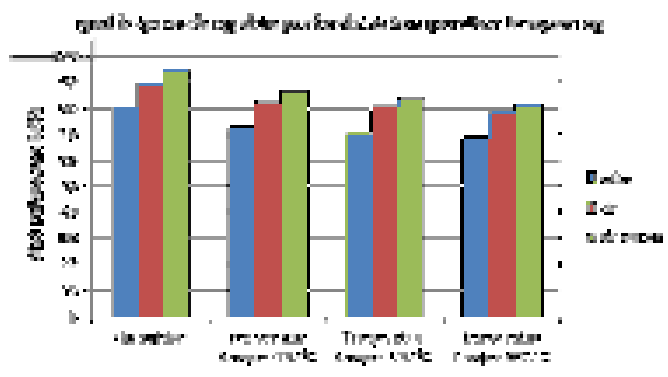

Gambar 9. Grafik quenching dan perbedaan temperatur tempering

Hal tersebut sesuai dengan teori yang menyatakan, Pengaruh suhu penemperan terhadap sifat-sifat baja adalah apabila suhu tempering semaking tinggi maka mempunyai sifat kekerasan yang semakin menurun atau nilai kekerasan semakin kecil. Dan dapat dlihat kurva quenching dan perbandingan temperatur tempering pada gambar dibawah.

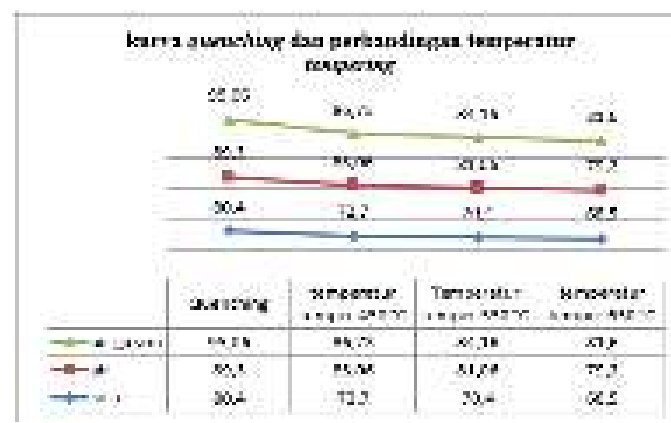

Gambar 10. Kurva quenching dan perbandingan temperatur tempering

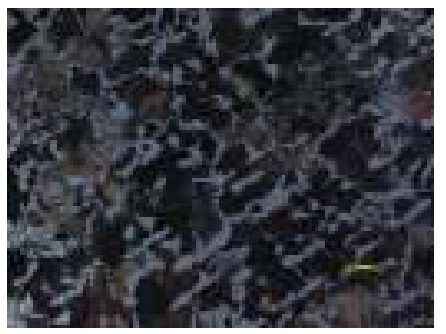

Gambar 11. Struktur Baja AISI 1045 Tanpa Perlakuan (raw material)
Gambar 11 merupakan hasil pengamatan metalografi, diperoleh foto struktur mikro specimen. Dalam hal ini struktur mikro yang diamati meliputi struktur mikro tanpa perlakuan. Stuktur mikro pada baja AISI 1045 dapat terlihat pada gambar stuktur baja raw material belum terjadi fasa matensit, yang terlihat bahwa struktur yang terbentuk adalah, pearlite (berwarna gelap atau hitam) dengan jumlah struktur berkisas 74 dan ferrite jumlah strukturnya berkisar 99 (berwarna terang). Pada temperatur austenite mendapat laju pendinginan lambat dengan udara ke temperatur kamar maka struktur yang terbentuk adalah pearlite. Pearlite merupakan campuran dari ferrite dan sementite. Pada gambar diatas menunjukkan laju pendinginan lambat sehingga transformasi austenite yang terbentuk adalah pearlite dan ferrite.

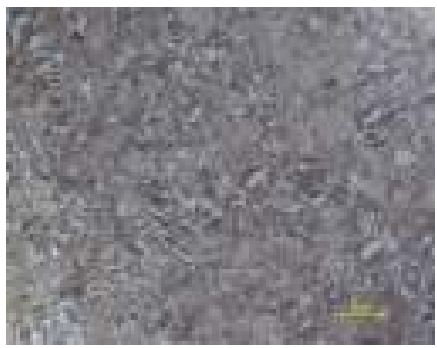

Gambar 12. Struktur baja AISI 1045

Quenching media air garam pembesaran 200X

Pada gambar 12 adalah struktur mikro pada baja aisi 1045 mengunakan media air garam dan bukaan katup penuh $180^{\circ}$ dengan debit aliran $10 \mathrm{Lpm}$. Pada proses quenching mengunakan media air garam dan bukaan katup penuh $180^{\circ}$ berhasil meningkatkan nilai kekerasan pada baja dan membentuk struktur martensit pada baja AISI 1045 akibat proses pendinginan cepat pada temperatur $800{ }^{\circ} \mathrm{C}$. struktur mikro ferrit eutectoid makin sedikit yang terbentuk diperkirakan kecepatan dalam pendinginan. Struktur martensite terlihat berwarna putih, berbentuk seperti butiranbutiran, penyebarannya yang hampir menyeluruh menandakan spesimen ini bersifat keras dan getas.

Dari gambar 13 berikut terlihat foto struktur mikro spesimen. Dalam hal ini struktur mikro 
yang diamati meliputi struktur mikro quenching-tempering. Setelah proses quenching selesai dilanjutkan dengan pemanasan kembali (tempering) dengan suhu $650{ }^{\circ} \mathrm{C}$. Sehingga gambar diatas terlihat struktur yang terbentuk adalah temper martensit yang tampak garis-garis yang semakin halus lagi berwarna putih dan pearlite yang tampak bintik-bintik berwarna hitam dengan matriks temper martensit serta austenite sisa yang tidak sempat bertransformasi. Dengan terbentuknya temper martensit yang semakin halus dan sebagian pearlite telah menyebar berbentuk bintik halus menyebabkan kekerasannya semakin menurun dan baja mengalami ulet.

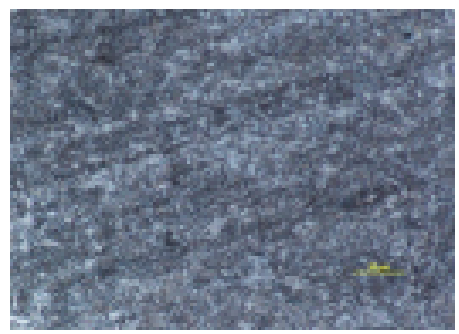

Gambar 13. Struktur baja AISI 1045 tempering temperatur $650{ }^{\circ} \mathrm{C}$ pembesaran $200 \mathrm{X}$

\section{KESIMPULAN}

Adapun kesimpulan yang didapatkan berdasarkan penelitian mengenai pengaruh temperatur tempering dan variasi media pendingin yang disirkulasikan pada proses quenching terhadap kekerasan dan struktur mikro baja AISI 1045 adalah sebagai berikut:

1. Nilai kekerasan rata-rata maksimum pada proses quenching yaitu pada media air garam sebesar $96 \mathrm{HRB}$

2. Nilai kekerasan pada baja tanpa perlakuan (raw material) sebesar 61,33 HRB

3. Media pendingin air dengan bukaan katup penuh mendapatkan nilai kekerasan masing-masing sebesar 89,3 HRB, $89 \mathrm{HRB}$ dan 89,6 HRB

4. Media pendingin air garam bukaan katup penuh mendapatkan nilai kekerasan masing-masing sebesar 94,6 HRB, $96 \mathrm{HRB}$ dan 94,6 HRB
5. Media pendingin solar dengan bukaan katup penuh mendapatkan nilai kekerasan masing-masing sebesar 80,6 HRB, 79,3 HRB dan 81,3 HRB

6. Variasi media yang paling baik yaitu medai air garam karena menghasilkan nilai kekerasan baja dan menghasilkan martensite yang banyak

7. Proses tempering dari temperatur $450{ }^{\circ} \mathrm{C}$ ke temperatur $650{ }^{\circ} \mathrm{C}$ mengalami penurunan. Hal tersebut sesuai dengan teori yang menyatakan, Pengaruh suhu penemperan terhadap sifat-sifat baja adalah apabila suhu tempering semakin tinggi maka mempunyai sifat kekerasan yang semakin menurun.

8. Laju pendinginan dan viskositas fluida mempengaruhi kekerasan suatu baja, karena semakin lambat laju pendinginan dan semakin tinggi viskositas maka kekerasan akan semakin tinggi

9. Struktur mikro yang terbentuk proses quenching adalah martensite lalu setelah proses temper struktur mikro menjadi temper martensite serta struktur lain yang terbentuk adalah austenite sisa.

\section{DAFTAR PUSTAKA}

[1] Azizi, miftah, 2018. Pengaruh Suhu Quench Dan Temper Pada Proses Pengerasan Permukaan Baja Aisi 1054. Universitas Wahid Hasyim Semarang.

[2] Haryadi, Gunawan Dwi, 2006. Pengaruh Suhu Tempering Terhadap Kekerasan, Kekuatan Tarik Dan Struktur Mikro Pada Baja K-460. Volume 8, no 2 april 2006 hal: $1-8$

[3] Mizar Susri, 2015. Analisis Kekerasan Dan Struktur Mikro Terhadap Variasi Temperatur Tempering Pada Baja Aisi 4104. Jurusan Teknik Mesin, Institut Teknologi Medan

[4] Mustofa Z, 2016. Analisa Pengaruh Pendingin Terhadap Kekerasan Bahan Aisi 1045 Pada Proses Heat Treatment. Universitas Nusantara Persatuan Guru Republik Indonesia. UN PGRI Kediri.

[5] Nugroho, Sri dan Haryadi, Gunawan Dwi. 2005. Pengaruh media Quenching Air Tersirkulasi (Circulated Water) Terhadap Struktur Mikro Dan Kekerasan Pada Baja AISI 1045. Jurnal Rotasi Volume 7 
Nomor 1.

[6] Pranomo, Agus. 2011. Jurnal Ilmiah Teknik Mesin CakraM. Vol. 5. No. 1. April 2011. Hal 32-38. Banten.

[7] Yusman F, 2018. Pengaruh Media Pendingin Pada Proses Quenching Terhadap Kekerasan Dan Strukur Mikro Baja Aisi 1045. Universitas lampung. Bandar Lampung. 